\title{
Preparation of trialkylgermyl and -stannyl derivatives of methyl isothiocyanate by in situ trapping of anionic intermediates with chloro(trialkyl)germane and -stannanes
}

\author{
Lambert Brandsma ${ }^{a}$ and Nina A. Nedolya ${ }^{b}$ \\ a Julianalaan 273, NL-3722 GN Bilthoven, The Netherlands \\ ${ }^{b}$ A. E. Favorsky Irkutsk Institute of Chemistry, Siberian Branch of the Russian Academy of \\ Sciences, RU-664033 Irkutsk, Russia \\ E-mail: l.brandsma@wxs.nl
}

\begin{abstract}
Dedicated to Academician Michael G. Voronkov on the occasion of his $\mathbf{8 0}^{\text {th }}$ birthday (received 21 Mar 01; accepted 25 Oct 01; published on the web 02 Nov 01)
\end{abstract}

\begin{abstract}
Addition of an ether solution of one or two equivalents of lithium diisopropylamide to strongly cooled 1:1- or 1:3-molar mixtures of methyl isothiocyanate and chloro(trimethyl)germane in THF afforded (isothiocyanatomethyl)(trimethyl)germane and [isothiocyanato (trimethylgermyl)methyl](trimethyl)germane, respectively, in fair to good yields. Using this in situ trapping procedure (isothiocyanatomethyl)(trimethyl)stannane and tributyl (isothiocyanatomethyl)stannane were obtained in high yields from the corresponding chloro (trialkyl)stannanes and methyl isothiocyanate.
\end{abstract}

Keywords: Lithium diisopropylamide, deprotonation, (trimethylgermyl)methyl isothiocyanates, (trialkylstannyl)methyl isothiocyanates

\section{Introduction}

As part of our investigations with heterocumulenes and polar organometallics ${ }^{1-3}$ we recently developed a method for the convenient preparation of silylated methyl isothiocyanates ${ }^{4}$ (Scheme 1). Our procedure is similar to the one used to trap short-lived anions generated from allylic and benzylic halides ${ }^{5}$ and consists of the in situ trapping with chloro(trimethyl)silane of anion 2 , generated from methyl isothiocyanate 1 and lithium diisopropylamide (LDA). Depending on the molar ratios of the reactants, we succeeded in obtaining mono-, bis- and tris(trimethylsilyl)substituted methyl isothiocyanates 3, 4 and 5 in good to excellent yields.

Applying similar procedures we have successfully introduced one and two silyl groups into benzyl isothiocyanate. ${ }^{6}$ We wish to point out in this connection that generation of isothiocyanate 
anions and their functionalization with electrophiles in two separate and consecutive operations appears to be unfeasible. Attempts to realize this two step reaction sequence have resulted in the formation of thiazole and imidazole derivatives. ${ }^{7}$

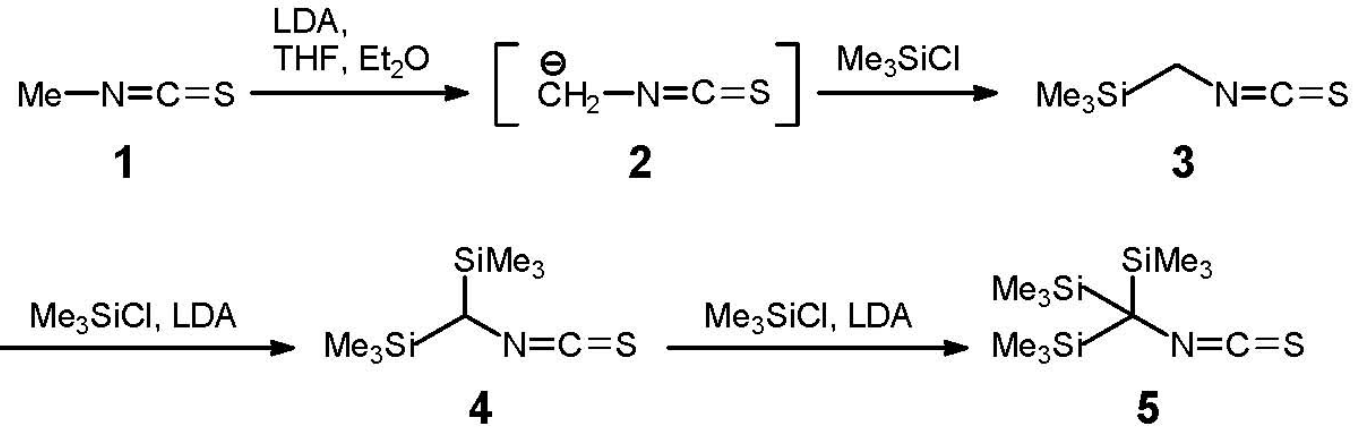

\section{Scheme 1}

\section{Results and Discussion}

To our knowledge halo(trialkyl)germanes and -stannanes have not been used so far as reagents in in situ trapping experiments. Especially, isothiocyanatoalkylstannanes may have synthetic importance in view of the possibility to substitute a trialkylstannyl moiety by electrophilic groups such as an acyl group. In analogy with the trapping experiments with chloro(trimethyl)silane, mixtures of chloro(trimethyl)germane hloro(trimethyl)stannane or tributyl(chloro)stannane and methyl isothiocyanate (1) were treated with solutions of LDA (Scheme 2).

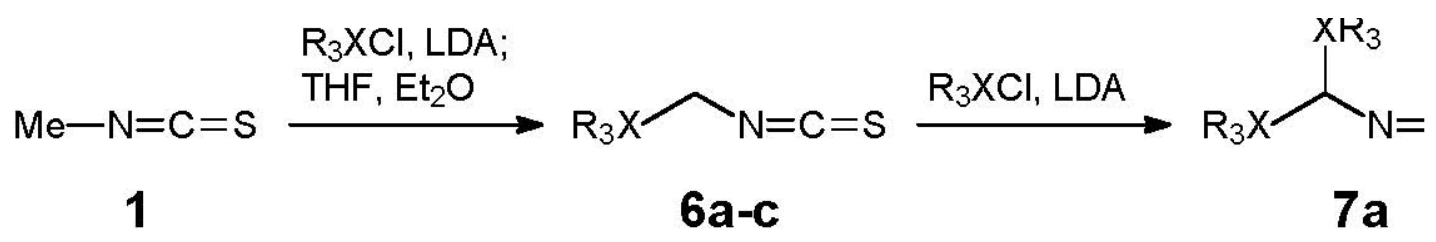

a: $X=G e, R=M e ; b: X=S n, R=M e ; c: X=S n, R=B u$

\section{Scheme 2}

Using an equimolar ratio of 1, LDA, and chloro(trimethyl)germane fairly pure (isothiocyanatomethyl)(trimethyl)germane (6a) was obtained in about 55\% yield, together with a small amount of [isothiocyanato(trimethylgermyl)methyl](trimethyl)germane (7a). The latter was isolated as the main product $(50 \%)$ by fractional distillation of the crude product (7a $64 \%$, 6a $27 \%$ ) obtained by treatment of a 1:2 molar mixture of 1 and chloro(trimethyl)germane with 2 molar equivalents of LDA. 
In an attempt to prepare the tris-germylated methyl isothiocyanate we added three equivalents of LDA to a 1:3 molar mixture of $\mathbf{1}$ and chloro(trimethyl)germane. However, in the crude product the expected compound was present only in $14 \%$, distillation of the crude product afforded 7a in $73 \%$ yield. It seems that the removal of the methine proton from 7a proceeds less effectively, possibly due to steric hindrance.

The preparation of (isothiocyanatomethyl)(trimethyl)stannane (6b) was achieved with excellent results using 1 and LDA in excess with respect to chloro(trimethyl)stannane. A similar procedure with equal molar amounts of 1, LDA and tributyl(chloro)stannane afforded tributyl(isothiocyanatomethyl)stannane (6c) in high yield. No attempts were made to introduce two or three trialkylstannyl groups.

\section{Experimental Section}

General Procedures. Solvents and diisopropylamine were dried over machine-powdered potassium hydroxide and distilled after filtration. Methyl isothiocyanate and tributyl(chloro)stannane are commercially available (from Aldrich). Solutions of LDA were prepared by adding diisopropylamine at approx. $-10{ }^{\circ} \mathrm{C}$ to a solution of $n$-butyllithium in hexane (1.6 M; Chemetall) and diethyl ether or THF. Chloro(trimethyl)germane and tetramethylstannane, from which chloro(trimethyl)stannane was prepared, were gifts (from Dr. K. D. Bos). Liquid nitrogen was used as coolant of the reactions. The reaction products were isolated by dry work-up: After removal of the solvents on the rotary evaporator under reduced pressure, about $70 \mathrm{~mL}$ of pentane was added to the syrupy residue; lithium chloride was filtered off and rinsed with pentane; after concentration of the pentane solutions under reduced pressure, the crude product was subjected to vacuum distillation.

${ }^{1}$ H NMR spectra were recorded on a Varian EM-390 (90 MHz) spectrometer. Chemical shifts are given in ppm relative to TMS, carbon tetrachloride was used as solvent. IR spectra were recorded on a Perkin-Elmer spectrophotometer (model 283). GLC analyses were carried out on a Varian 3400 gas chromatograph (15 m capillary column coated with a $1.5 \mu$ DB-5, internal diameter $0.53 \mathrm{~mm})$.

(Isothiocyanatomethyl)(trimethyl)germane (6a). To a stirred solution of chloro(trimethyl) germane $(3.7 \mathrm{~g}, 24.2 \mathrm{mmol})$ and $\mathbf{1}(1.78 \mathrm{~g}, 24.4 \mathrm{mmol})$ in THF $(50 \mathrm{~mL})$ a cold (approx. $\left.-10^{\circ} \mathrm{C}\right)$ solution of LDA $(2.57 \mathrm{~g}, 24.0 \mathrm{mmol})$ in hexane $(15 \mathrm{~mL})$, THF $(30 \mathrm{~mL})$ and ether $(30 \mathrm{~mL})$ was added over 30 min from a dropping funnel with cooling between -100 to $-85{ }^{\circ} \mathrm{C}$. After the addition, the reaction mixture was stirred at approx. $-80{ }^{\circ} \mathrm{C}$ for $35-40 \mathrm{~min}$, then the cooling bath was removed, and dry work-up of the reaction mixture was carried out. According to GLCanalysis the crude product $(3.8 \mathrm{~g})$ contained a mixture of $6 \mathbf{a}(73 \%)$ and $7 \mathbf{a}(19 \%)$. The green residue after removal of solvents was carefully distilled in vacuo to give 6a $(2.4 \mathrm{~g}$, 53\%; purity $92 \%$ by GLC), bp $40-50{ }^{\circ} \mathrm{C}(0.8 \mathrm{~mm} \mathrm{Hg}) ; n=1.5235$. IR (film): $2100-2180 \mathrm{~cm}^{-1}(\mathrm{~N}=\mathrm{C}=\mathrm{S}) ;{ }^{1} \mathrm{H}$ 
NMR $\left(90 \mathrm{MHz}, \mathrm{CCl}_{4}\right): \delta 3.08\left(2 \mathrm{H}, \mathrm{s}, \mathrm{CH}_{2} \mathrm{~N}\right), 0.40\left[9 \mathrm{H}, \mathrm{s},\left(\mathrm{CH}_{3}\right)_{3} \mathrm{Ge}\right]$. Anal. Calcd for $\mathrm{C}_{5} \mathrm{H}_{11} \mathrm{GeNS}$ (189.82): C, 31.64; H, 5.84; Ge, 38.25; N, 7.38; S, 16.89. Found: C, 31.66; H, 6.00; Ge, 37.90; N, 7.49; S, 16.95. The higher boiling fraction consisted mainly of 7a.

[Isothiocyanato(trimethylgermyl)methyl](trimethyl)germane (7a). To a stirred solution of chloro(trimethyl)germane $(9.3 \mathrm{~g}, 60.7 \mathrm{mmol})$ and $1(2.3 \mathrm{~g}, 31.5 \mathrm{mmol})$ in THF $(50 \mathrm{~mL})$ a cold (approx. $\left.-10{ }^{\circ} \mathrm{C}\right)$ solution of LDA $(6.51 \mathrm{~g}, 60.8 \mathrm{mmol})$ in hexane $(38 \mathrm{~mL})$, THF $(60 \mathrm{~mL})$ and ether $(60 \mathrm{~mL})$ was added from a dropping funnel over 55 min with cooling between -100 and $80{ }^{\circ} \mathrm{C}$. After the addition, the reaction mixture was stirred at -100 to $-70{ }^{\circ} \mathrm{C}$ for $15 \mathrm{~min}$, then the cooling bath was removed, and dry work-up of the reaction mixture was carried out. According to GLC-analysis the crude product $(7.85 \mathrm{~g})$ contained a mixture of $7 \mathbf{a}(64 \%)$ and $6 \mathbf{6}(27 \%)$. The light-yellow residue after removal of solvents was carefully distilled in vacuo to give $7 \mathbf{a}$ (4.6 g, $50 \%$; purity $97 \%$ by GLC), bp $70-80{ }^{\circ} \mathrm{C}(0.5 \mathrm{~mm} \mathrm{Hg}) ; n=1.5330 ; \mathrm{mp} 31-33{ }^{\circ} \mathrm{C}$. IR (film): 2080-2160 $\mathrm{cm}^{-1}(\mathrm{~N}=\mathrm{C}=\mathrm{S}) ;{ }^{1} \mathrm{H}$ NMR $\left(90 \mathrm{MHz}, \mathrm{CCl}_{4}\right): \delta 2.75(1 \mathrm{H}, \mathrm{s}, \mathrm{HC}-\mathrm{N}), 0.35[18 \mathrm{H}, \mathrm{s}, 2$ $\left(\mathrm{CH}_{3}\right)_{3} \mathrm{Ge}$. Anal. Calcd for $\mathrm{C}_{8} \mathrm{H}_{19} \mathrm{Ge}_{2} \mathrm{NS}$ (306.53): C, 31.35; H, 6.25; Ge, 47.38; N, 4.57; S, 10.46. Found: C, 31.93; H, 6.40; Ge, 46.50; N, 4.67; S, 10.50. The lower boiling fraction consisted mainly of $\mathbf{6 a}$.

[Isothiocyanato(trimethylgermyl)methyl](trimethyl)germane (7a). To a stirred solution of chloro(trimethyl)germane (15 g, $98.0 \mathrm{mmol})$ and $\mathbf{1}(2.3 \mathrm{~g}, 31.5 \mathrm{mmol})$ in THF $(50 \mathrm{~mL})$ a cold (approx. $\left.-10^{\circ} \mathrm{C}\right)$ solution of LDA $(10.1 \mathrm{~g}, 94.4 \mathrm{mmol})$ in hexane $(59 \mathrm{~mL})$, THF $(60 \mathrm{~mL})$ and ether $(60 \mathrm{~mL})$ was added over $80 \mathrm{~min}$ with cooling between -110 and $-75^{\circ} \mathrm{C}$. After the addition, the reaction mixture was stirred at -100 to $-75{ }^{\circ} \mathrm{C}$ for $60 \mathrm{~min}$, then the cooling bath was removed, and dry work-up of the reaction mixture was carried out. According to GLC-analysis the crude product (14 g) contained 6a (approx. 1\%), 7a (68\%) and the tris-germylated compound (14\%). The brown residue after removal of the solvents was carefully distilled in vacuo to give the 7a (6.7 g, 73\%; purity $93 \%$ by GLC), bp approx. $87^{\circ} \mathrm{C}$ (approx. $0.5 \mathrm{~mm} \mathrm{Hg}$ ); $n=1.5307$; mp 27-30 ${ }^{\circ} \mathrm{C}$. IR (film): 2080-2160 $\mathrm{cm}^{-1}(\mathrm{~N}=\mathrm{C}=\mathrm{S}) ;{ }^{1} \mathrm{H}$ NMR $\left(90 \mathrm{MHz}, \mathrm{CCl}_{4}\right): \delta 2.75(1 \mathrm{H}, \mathrm{s}, \mathrm{HC}-$ $\mathrm{N}), 0.35\left[18 \mathrm{H}, \mathrm{s}, 2\left(\mathrm{CH}_{3}\right)_{3} \mathrm{Ge}\right]$. The lower boiling fraction (bp $40-85{ }^{\circ} \mathrm{C}$ at approx. $0.5 \mathrm{~mm} \mathrm{Hg}$ ) consisted mainly of 7a $(86 \%)$ and $6 \mathbf{a}(6 \%)$. The small residue from the distillation was identified by GLC, IR and ${ }^{1} \mathrm{H}$ NMR as [isothiocyanato[bis(trimethylgermyl)]methyl](trimethyl)-germane.

(Isothiocyanatomethyl)(trimethyl)stannane (6b). To a stirred solution of chloro(trimethyl)stannane (9.95 g, $50.0 \mathrm{mmol})$ and $1(5.2 \mathrm{~g}, 71.2 \mathrm{mmol})$ in THF $(70 \mathrm{~mL})$ a cold (approx. $-10{ }^{\circ} \mathrm{C}$ ) solution of LDA $(6.51 \mathrm{~g}, 60.8 \mathrm{mmol})$ in hexane $(38 \mathrm{~mL})$, THF $(30 \mathrm{~mL})$ and ether $(30 \mathrm{~mL})$ was added over $30 \mathrm{~min}$ from a dropping funnel with cooling between -100 to $-85{ }^{\circ} \mathrm{C}$. After the addition, the reaction mixture was stirred at -85 to $-80^{\circ} \mathrm{C}$ for $15 \mathrm{~min}$, then the cooling bath was removed, and dry work-up of the reaction mixture was carried out. The residue was carefully distilled in vacuo to give $\mathbf{6 b}\left(9.7 \mathrm{~g}, 82 \%\right.$; purity approx. $100 \%$ by GLC), bp approx. $100{ }^{\circ} \mathrm{C}$ (approx. $2 \mathrm{~mm} \mathrm{Hg}) ; n=1.5665$. IR (film): 2100-2180 $\mathrm{cm}^{-1}(\mathrm{~N}=\mathrm{C}=\mathrm{S}) ;{ }^{1} \mathrm{H} \mathrm{NMR}\left(90 \mathrm{MHz}, \mathrm{CCl}_{4}\right)$ : $\delta 3.20\left(2 \mathrm{H}, \mathrm{s}, \mathrm{CH}_{2} \mathrm{~N}\right), 0.35$ [9H, s, $\left(\mathrm{CH}_{3}\right)_{3} \mathrm{Sn}$ ]. Anal. Calcd for $\mathrm{C}_{5} \mathrm{H}_{11} \mathrm{NSSn}$ (235.92): C, 25.45; H, 4.70; N, 5.94; S, 13.59; Sn, 50.32. Found: C, 25.88; H, 5.11; N, 5.88; S, 13.46; Sn, 49.67.

Tributyl(isothiocyanatomethyl)stannane (6c). To a stirred solution of tributyl(chloro)stannane 
(8.47 g, $26.0 \mathrm{mmol})$ and 1 (1.89 g, $25.9 \mathrm{mmol})$ in THF $(50 \mathrm{~mL})$ a cold (approx. $\left.-10{ }^{\circ} \mathrm{C}\right)$ solution of LDA (2.91 g, $27.2 \mathrm{mmol})$ in hexane $(17 \mathrm{~mL})$, THF $(30 \mathrm{~mL})$ and ether $(30 \mathrm{~mL})$ was added from a dropping funnel over 60 min with cooling between -100 and $-70{ }^{\circ} \mathrm{C}$ After the addition, the reaction mixture was stirred at -100 to $-70{ }^{\circ} \mathrm{C}$ for $70 \mathrm{~min}$, then the cooling bath was removed, and dry work-up of the reaction mixture was carried out. The residue $(7.7 \mathrm{~g})$ was carefully distilled in vacuo to give 6c (7.2 g, 77\%; purity approx. 99\% by GLC), bp $130-140{ }^{\circ} \mathrm{C}$ (approx. $0.8 \mathrm{~mm} \mathrm{Hg}) ; n=1.5265$. IR (film): $2100-2180 \mathrm{~cm}^{-1}(\mathrm{~N}=\mathrm{C}=\mathrm{S}) ;{ }^{1} \mathrm{H}$ NMR $(90 \mathrm{MHz}$, $\left.\mathrm{CCl}_{4}\right): \delta 3.17\left(2 \mathrm{H}, \mathrm{s}, \mathrm{CH}_{2} \mathrm{~N}\right), 1.40\left(12 \mathrm{H}, \mathrm{m}, 3 \beta, \gamma-\mathrm{CH}_{2} \mathrm{CH}_{2}\right), 0.98$ [15H, m, $3 \mathrm{CH}_{3}$ and $\left.\left(\mathrm{CH}_{2}\right)_{3} \mathrm{Sn}\right]$. Anal. Calcd for $\mathrm{C}_{14} \mathrm{H}_{29} \mathrm{NSSn}$ (362.16): C, 46.43; H, 8.07; N, 3.87; S, 8.85. Found: C, 48.08; H, $9.47 ; \mathrm{N}, 3.75 ; \mathrm{S}, 8.86$.

\section{Acknowledgements}

We are indebted to Dr. K. D. Bos for supplying us with chloro(trimethyl)germane and tetramethylstannane, from which we prepared chloro(trimethyl)stannane.

\section{References}

1. de Jong, R. L. P.; Verkruijsse, H. D.; Brandsma, L. In Perspectives in the Organic Chemistry of Sulfur, Zwanenburg, B.; Klunder, A. J. H. Eds., Elsevier: Amsterdam, 1987; p. 105.

2. (a) Brandsma, L.; Nedolya, N. A.; Tarasova, O. A.; Trofimov, B. A. Chem. Heterocycl. Compd. (N.Y.). 2000, 36, 1241. (b) Brandsma, L.; Nedolya, N. A.; Tarasova, O. A.; Trofimov, B. A. Khim. Geterotsikl. Soedin. 2000, 1443. (c) Brandsma, L. Eur. J. Org. Chem. 2001, in press.

3. Nedolya N.A., Novel Chemistry Based on Isothiocyanates and Polar Organometallics. Thesis Utrecht University, 1999.

4. Brandsma, L.; Nedolya, N. A.; Verkruijsse, H. D.; Trofimov, B. A. Synthesis 1997, 423.

5. Andringa, H.; Heus-Kloos, Y. A.; Brandsma, L. J. Organomet. Chem. 1987, 336, C41.

6. Brandsma, L.; Nedolya, N. A.; Trofimov, B. A. Mendeleev Commun. 1997, 232.

7. Nedolya, N. A.; Brandsma, L.; Trofimov, B. A. Tetrahedron Lett. 1997, 38, 6279. 